\title{
Effect of different winter pruning systems on grapes produced
}

\author{
Claudio Caprara, ${ }^{1}$ Fabio Pezzi ${ }^{2}$ \\ ${ }^{1}$ Department of Agricultural Sciences, University of Bologna, Italy; ${ }^{2}$ Department of Agrifood \\ Sciences and Technologies, University of Bologna, Italy
}

\begin{abstract}
The purpose of these trials was to evaluate possible effects on properties of grapes, particularly the physical and mechanical features, depending on the winter pruning system. The following pruning techniques were carried out: manual pruning $(\mathrm{m})$; mechanical pruning (M); mechanical pre-pruning and subsequent manual finishing ( $\mathrm{Mm})$; mechanical pre-pruning and contemporary fast manual finishing, using a wagon facility with two operators equipped with pneumatic scissors (Mw). The trials were carried out on Sangiovese trained to spurred cordon. During the trials were measured: time and cost of pruning, quality of pruning and the vegetative-productive response of vines. During grape harvesting a consolidated analytical method of texture analysis was applied to evaluate the physical parameters of grapevine cultivar: pedicel detachment, skin perforation, skin thickness, grape features as hardness, cohesiveness, springiness. Analysis of working time showed that the manual pruning (m) determined a greater commitment of time, while the mechanized pruning (M) presented a time reduction of $95 \%$. The two mechanized pruning associated with manual finishing reduced the time of $21 \%(\mathrm{Mm})$ and $69 \%$ (Mw). The lowering cost is less evident but important anyway. Regarding the quality of pruning, the increase in the level of mechanization has produced an increase of spurs and buds density. It was also detected a higher percentage of damaged spurs and in wrong position. The increasing of mechanization levels of pruning also has produced smaller and sparser bunches with smaller berries. The study of mechanical properties of berries showed significant differences in the mechanical behaviours of the different pruning tests. The mechanized
\end{abstract}

Correspondence: Claudio Caprara, Department of Agricultural Sciences, University of Bologna, Via G. Fanin 48, 40127 Bologna, Italy. Tel. +39.051.2096192.

E-mail: claudio.caprara@unibo.it

Keywords: mechanical pruning, vineyard, grape mechanical properties.

Contributions: the authors contributed equally.

Conflict of interests: the authors declare no potential conflict of interests.

(C) Copyright C. Caprara, F. Pezzi, 2013

Licensee PAGEPress, Italy

Journal of Agricultural Engineering 2013; XLIV(s2):e85

doi:10.4081/jae.2013.s2.e85

This article is distributed under the terms of the Creative Commons Attribution Noncommercial License (by-nc 3.0) which permits any noncommercial use, distribution, and reproduction in any medium, provided the original author(s) and source are credited. pruning presented higher values for the pedicel detachment, skin perforation and cohesiveness, while it gave lower values for thickness of skin and springiness. The results showed that mechanical pruning can modify properties of the berries which influence mechanical harvesting on vineyard.

\section{Introduction}

Winter pruning of the vineyard is one of the most important cultural practices for its physiological and productive influence on plants. In Italy the manual pruning is still prevalent and appreciated for quality of work, when performed by experienced operators.

In recent years, the difficulty to have skilled labor and the overall growth of production costs have increased the interest towards the mechanical pruning. After about forty years of experimentation in Italy (Baldini and Intrieri, 1984; Gubiani et al., 1994; Intrieri and Poni, 1995; Brancadoro et al., 1997; Intrieri et al., 1999; Poni et al., 2004), the approach is still partial and mechanical pruning is done mostly as an operation that includes a final manual trimming. Against clear economic advantages (Pergher and Gubiani, 1995; Brancadoro and Marmugi, 1997; Pezzi and Bordini 2006), the main concerns that limit the mechanical pruning are the vegetative and productive behavior of plants, especially their capacity of spurs renewing and control of buds number. Other problems may involve the plant health area for the greater probability of wood disease attributable to drying up of shoots aged or damaged by the machines.

To provide further information to winegrowers, an experimentation was begun a decade ago that aims to evaluate the agronomical, economical and operational aspects of pruning mechanization (Pezzi and Bordini, 2006). In the last year the study also wanted to test the possible influences that the mechanical pruning can have on physical and mechanical characteristics of the grapes (Pezzi et al., 2012), because these factors could affect the mechanization of other operations, in particular the harvesting.

The aim of this research was to evaluate the effects of mechanical pruning on Sangiovese, one of the most diffused vines in Italy where mechanization is increasing.

\section{Materials and Methods}

The trial of mechanical pruning is in progress at the experimental farm "Terre Naldi" in Faenza (Italy) which collaborates with the University of Bologna. In this farm some grape varieties, grown with different forms of training systems, are pruned with different levels of mechanization to evaluate the performance and cost of pruning techniques, the quality of work and plant behavior.

The trials were carried out on Sangiovese vines grown on medium 
fertility flat land. The vineyard was trained to spurred cordon, with a plant distance of $1.1 \mathrm{~m}$ by $2.5 \mathrm{~m}$.

The considered tests for winter pruning were:

(m) - manual pruning, done by operators who proceeded walking and used manual scissors. The work plan provided 7 spurs plant ${ }^{-1}$ with 2 buds.

(Mm) - mechanical pruning and subsequent manual finishing. The work plan included a cut of the spurs by the mechanical pruner to 2 buds and a subsequent manual thinning of the spurs done by operators who proceeded walking and used manual scissors.

(Mw) - mechanical pruning and contemporary manual finishing, performed with pneumatic shears by two operators placed on a wagon trailed by the tractor carrying the mechanical pruner. The work plan included a cut of the spurs by the mechanical pruner to 1-2 buds and a quick manual thinning of the spurs, less accurate than tests $\mathrm{m}$ and $\mathrm{Mm}$.

(M) - mechanical pruning done only with the machine. The work plan included a cut of the spurs by the mechanical pruner to 1-2 buds.

The mechanical pruner was the "Trimmer" model by Tanesini Technology Company with a swinging cutter bar and a tool for vinebranch detachment. In the test the mechanical pruner has been set up raw straddling with three blades, to cut the cordon above and laterally in one step. The blade for horizontal cutting was mobile with spring return to overcome the poles. The machine has been carried anteriorly by a $59 \mathrm{~kW}$ four-wheel drive tractor. The wagon used had perimetral railings, systems for adjusting the height and the lateral displacement and a compressor for the supply of compressed air.

In each test we measured the work time, the result of pruning, and yield response. From the work time and the parameters listed in Table 1 it has been possible to make a hypothesis of cost (ASAE, 2011).

At harvest, the grapes were subjected to laboratory measurements with Texture Analyser (TA-HDi model by Stable Micro Systems, UK) to measure detachment of pedicel, break and thickness of skin (Figure 1) (ASAE, 1997; Stable Micro Systems, 2005). The Texture Profile Analysis (TPA) was also carried out obtaining several parameters including hardness, cohesiveness and springiness (Bourne, 2002; Rolle et al., 2011; Pezzi et al., 2012). Each test was carried out on 50 samples.

\section{Results}

The desired accuracy with manual pruning (m) and the need to manually remove the vine-branches from the wires has limited the forward speed of operators (Table 2) who worked with a frequency of 30 cut $\min ^{-1}$.

In the mechanical pruning $(\mathrm{M})$ the machine was used with a forward speed of only $1080 \mathrm{~m} \mathrm{~h}^{-1}$ to maintain high precision of height cutting.
In Mm test the machine forward speed was the same of M test. After the machine passage, the operators manually cut only spurs in excess advancing with speed almost double compared to that of $m$ test, keeping a cut frequency of 39 cut $\mathrm{min}^{-1}$.

In Mw test the forward speed was reduced to $580 \mathrm{~m} \mathrm{~h}^{-1}$ to allow an acceptable manual finishing. The cut frequency in this test was 50 and 35 cut $\mathrm{min}^{-1}$ respectively for the first and the second operator.

Consequently the unit effective working times were very different (Figure 2). Compared to $m$ test the mechanical pruning (M) reduced of $95 \%$ required time. Mechanical pruning and subsequent manual finishing $(\mathrm{Mm})$ allowed a reduction of $47 \%$ of working time, while mechani-

Table 1. Elements used for the economic evaluation.

\begin{tabular}{lc} 
Economic parameters & Values \\
Market price $(€)$ - MP & \\
- mechanical pruner & 9.500 \\
- wagon & 3.500 \\
Residual value - RV & $10 \% \mathrm{MP}$ \\
\hline Machine life - $\mathrm{N}$ & $2.000 \mathrm{~h}$ \\
Vineyard area & $10 \mathrm{ha}$ \\
\hline Max years of use - $\mathrm{n}$ & 10 \\
Fixed costs $(€$ year-1): & $(\mathrm{MP}-\mathrm{RV}) / \mathrm{n}$ \\
- amortisation & $5 \%(\mathrm{MP}+\mathrm{RV}) / 2$ \\
- interests & $3 \% \mathrm{MP}$ \\
- other costs & \\
\hline Variable costs $\left(€ \mathrm{~h}^{-1}\right)$ & $60 \% \mathrm{MP} / \mathrm{N}$ \\
- repairs & $10 \%$ working time \\
- maintenance & 35 \\
- tractor with operator & 12 \\
- labor & \\
\hline
\end{tabular}

Table 2. Results at harvest.

\begin{tabular}{lcccc} 
Tests & $\begin{array}{c}\text { Forward speed } \\
\text { Machine } \\
\left(\mathrm{m} \mathrm{h}^{-1}\right)\end{array}$ & $\begin{array}{c}\text { Labour } \\
\left(\mathrm{m} \mathrm{h}^{-1}\right)\end{array}$ & $\begin{array}{c}\text { Number of } \\
\text { (n) }\end{array}$ & $\begin{array}{c}\text { Operator's cut } \\
\text { frequency } \\
\text { (cut min }\end{array}$ \\
$\mathrm{m}$ & - & 48.6 & 1 & 30 \\
$\mathrm{Mm}$ & 1080 & 100.8 & 1 & 39 \\
\hline $\mathrm{Mw}$ & 576 & 576.0 & 2 & $50-37$ \\
$\mathrm{M}$ & 1080 & - & - & - \\
\hline
\end{tabular}

Table 3. Results of pruning tests.

\begin{tabular}{|c|c|c|c|c|c|c|c|c|}
\hline Tests & $\begin{array}{c}\text { Buds } \\
\text { (n plant }^{-1} \text { ) }\end{array}$ & $\begin{array}{c}\text { total } \\
\text { (n plant-1) }\end{array}$ & $\begin{array}{l}1 \text { bud } \\
(\%)\end{array}$ & $\begin{array}{c}2 \text { buds } \\
(\%)\end{array}$ & $\begin{array}{c}\text { Spurs } \\
3 \text { buds } \\
(\%)\end{array}$ & $\begin{array}{c}>3 \text { buds } \\
(\%)\end{array}$ & $\begin{array}{c}\text { damaged } \\
(\%)\end{array}$ & $\begin{array}{l}\text { well positioned } \\
(\%)\end{array}$ \\
\hline $\mathrm{m}$ & $15.29 \mathrm{a}^{1}$ & $7.33 \mathrm{a}$ & $22.85 \mathrm{ab}$ & $49.37 \mathrm{ab}$ & $26.85 \mathrm{a}$ & $0.93 \mathrm{a}$ & $0 \mathrm{a}$ & $89.32 \mathrm{c}$ \\
\hline $\mathrm{Mm}$ & $20.33 \mathrm{ab}$ & $10.17 \mathrm{~b}$ & $19.70 \mathrm{a}$ & $59.47 \mathrm{~b}$ & $19.23 \mathrm{a}$ & $1.60 \mathrm{a}$ & $2.95 \mathrm{~b}$ & $79.14 \mathrm{~b}$ \\
\hline $\mathrm{Mw}$ & $24.42 \mathrm{~b}$ & $14.17 \mathrm{c}$ & $46.36 \mathrm{c}$ & $38.69 \mathrm{a}$ & $12.78 \mathrm{a}$ & $2.17 \mathrm{a}$ & $1.74 \mathrm{ab}$ & $65.64 \mathrm{a}$ \\
\hline M & $35.46 \mathrm{c}$ & $17.58 \mathrm{~d}$ & 34.08 bc & $44.84 \mathrm{a}$ & $15.55 \mathrm{a}$ & $6.53 \mathrm{~b}$ & $4.11 \mathrm{~b}$ & $64.63 \mathrm{a}$ \\
\hline
\end{tabular}

${ }^{1}$ values followed by different letters within the same column differ statistically for $\mathrm{P} \leq 0.05$. 
cal pruning and contemporary manual finishing (Mw) allowed a reduction of $75 \%$.

Compared to $\mathrm{m}$ test, the unit costs calculated on 10 ha vineyard showed a clear advantage for $M$ test, with a saving of $71 \%$ equivalent to $703 € \mathrm{ha}^{-1}$ (Figure 2). The cost reduction for tests $\mathrm{Mm}$ and Mw was less important, respectively of $23 \%$ and $35 \%$.

The vineyard minimum sizes for economical purchase of the machine are of 3.9 ha for Mm method, 4.0 ha for Mw and 1.7 ha for M.

With regard to the result of pruning the four tests have been characterized by a different density of spurs and buds with values increasing with the mechanization level. The statistical analysis showed signifi-

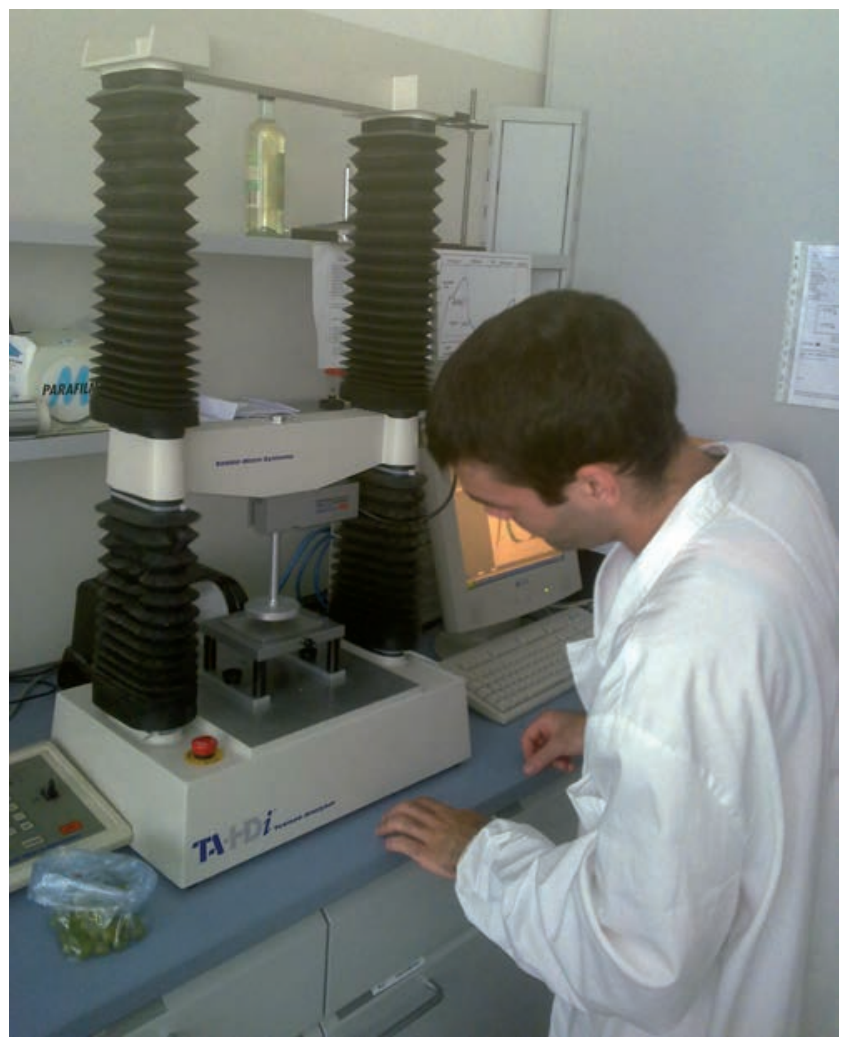

Figure 1. Texture analyzer used.
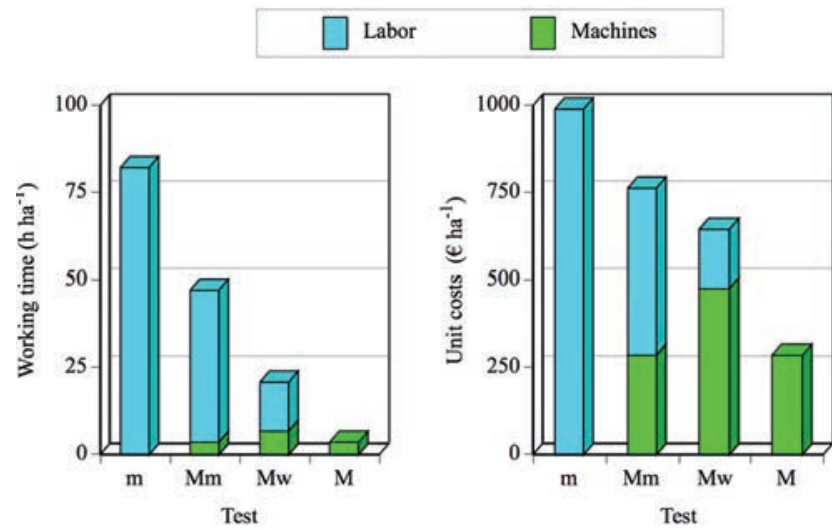

Figure 2. Working time and unit costs of the four pruning tests. cant differences among the tests (Table 3 ). With regard to the distribution of buds on each spur, it was observed that $\mathrm{m}$ and $\mathrm{Mm}$ tests have a wider presence of spurs with 2 buds, while $\mathrm{M}$ and Mw tests have a prevalence of spurs with 1 or 2 buds.

Using a low forward speed of machine, the presence of damaged spurs was low, with higher value for M test (4\%). The manual finishing after mechanical pruning ( $\mathrm{Mm}$ and $\mathrm{Mw}$ tests) reduced the damaged spurs. With manual pruning $(\mathrm{m})$ the spurs were well positioned on the upper side of the permanent cordon (89\%), while using only mechanical pruning $(\mathrm{M})$ the well positioned spurs were lower $(65 \%)$. The result was intermediate in $\mathrm{Mm}$ and $\mathrm{Mw}$ tests, where operators have improved the selection.

The greater presence of buds left by mechanical pruning did not affect the yield and its quality characteristics (Table 4 ). The production was instead different in bunch and berry sizes, with a weight reduction in more mechanized interventions ( $\mathrm{M}$ and $\mathrm{Mw}$ ).

Mechanical pruning has also affected the physical and mechanical features of grapes (Table 5). The two prunings more mechanized (M and $\mathrm{Mw}$ ) have increased the energy required for the pedicel detachment from berry. They also have influenced resistance and thickness of skin.

The results obtained using the Texture Profile Analyzer were quite interesting: the mechanical pruning test (M) was marked by lower values of cohesiveness and higher values of springiness and hardness (Table 6).

Table 4. Results at harvest.

\begin{tabular}{|c|c|c|c|c|c|c|}
\hline Tests & 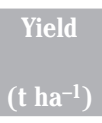 & $\begin{array}{c}\text { Weight of } \\
\text { bunches } \\
\text { (g) }\end{array}$ & $\begin{array}{l}\text { Weight of } \\
\text { berries } \\
\text { (g) }\end{array}$ & ${ }^{\circ}$ brix & $\begin{array}{l}\text { Acidity } \\
\left(\mathrm{g} \mathrm{L}^{-1}\right)\end{array}$ & $\mathrm{pH}$ \\
\hline $\mathrm{m}$ & $25.21 \mathrm{a}^{1}$ & $231 \mathrm{~b}$ & $2.50 \mathrm{bc}$ & $19.0 \mathrm{a}$ & $7.53 \mathrm{a}$ & $3.19 \mathrm{a}$ \\
\hline $\mathrm{Mm}$ & $24.85 \mathrm{a}$ & $244 \mathrm{~b}$ & $2.63 \mathrm{c}$ & $18.5 \mathrm{a}$ & $7.93 \mathrm{a}$ & $3.16 \mathrm{a}$ \\
\hline $\mathrm{Mw}$ & $23.15 \mathrm{a}$ & $229 a b$ & $2.40 \mathrm{ab}$ & $18.4 \mathrm{a}$ & $7.93 \mathrm{a}$ & $3.17 \mathrm{a}$ \\
\hline M & $25.33 \mathrm{a}$ & $215 \mathrm{a}$ & $2.31 \mathrm{a}$ & $18.6 \mathrm{a}$ & $7.33 \mathrm{a}$ & $3.18 \mathrm{a}$ \\
\hline
\end{tabular}

${ }^{1}$ values followed by different letters within the same column differ statistically for $\mathrm{P} \leq 0.05$.

Table 5. Mechanical parameters measured on berries.

\begin{tabular}{|c|c|c|c|c|c|}
\hline \multirow[t]{2}{*}{ Tests } & \multicolumn{2}{|c|}{$\begin{array}{l}\text { Detachment } \\
\text { of pedicel }\end{array}$} & \multirow{2}{*}{$\begin{array}{l}\text { Break of } \\
\text { skin } \\
\text { Force } \\
\text { (N) }\end{array}$} & \multicolumn{2}{|c|}{ Thickness of skin } \\
\hline & $\begin{array}{l}\text { Force } \\
(\mathrm{N})\end{array}$ & $\begin{array}{c}\text { Energy } \\
(\mathrm{mJ})\end{array}$ & & $\begin{array}{c}\text { Energy } \\
(\mathrm{mJ})\end{array}$ & $(\mathrm{mm})$ \\
\hline $\mathrm{m}$ & $5.41 \mathrm{a}^{1}$ & $18.81 \mathrm{a}$ & $4.62 \mathrm{a}$ & $13.26 \mathrm{ab}$ & $0.237 \mathrm{~b}$ \\
\hline $\mathrm{Mm}$ & $5.43 \mathrm{a}$ & $19.70 \mathrm{a}$ & $4.53 \mathrm{a}$ & $13.06 \mathrm{a}$ & $0.219 \mathrm{ab}$ \\
\hline Mw & $5.53 \mathrm{a}$ & $21.78 \mathrm{ab}$ & $5.00 \mathrm{~b}$ & $14.71 \mathrm{c}$ & $0.210 \mathrm{a}$ \\
\hline M & $5.78 \mathrm{a}$ & $24.83 \mathrm{~b}$ & $4.92 \mathrm{~b}$ & $14.26 \mathrm{bc}$ & $0.210 \mathrm{a}$ \\
\hline
\end{tabular}

${ }_{1}$ values followed by different letters within the same column differ statistically for $P \leq 0.05$.

Table 6. Texture Profile analyzer parameters.

\begin{tabular}{lccc} 
Tests & Hardness & Cohesiveness & Springiness \\
& $(\mathrm{N})$ & & \\
$\mathrm{m}$ & $4.73 \mathrm{~b}^{1}$ & $0.451 \mathrm{~b}$ & $0.185 \mathrm{a}$ \\
$\mathrm{Mm}$ & $4.63 \mathrm{ab}$ & $0.446 \mathrm{ab}$ & $0.184 \mathrm{a}$ \\
\hline $\mathrm{Mw}$ & $4.51 \mathrm{a}$ & $0.450 \mathrm{~b}$ & $0.187 \mathrm{a}$ \\
$\mathrm{M}$ & $4.92 \mathrm{c}$ & $0.443 \mathrm{a}$ & $0.197 \mathrm{~b}$ \\
\hline
\end{tabular}

1 values followed by different letters within the same column differ statistically for $\mathrm{P} \leq 0.05$. 


\section{Conclusions}

The evaluation of different levels of mechanization in the winter pruning of the Sangiovese grapes has provided some useful information to winegrowers for the choice of technique to use.

The operational and economical aspects repeated generally those already in evidence from other experiences and they gave very favorable indications to the total or partial application of mechanical pruning.

Mechanical pruning performed carefully by the tractor driver has allowed an acceptable quality of intervention by size, positioning and integrity of the spurs. The possibility of completing mechanical pruning with a more or less careful manual finishing can improve the result by removing part of the less suitable spurs and reducing the number of buds.

The adaptability of plants to the higher number of buds left by mechanical pruning appears positive with a reduction in the size of bunches and berries. The modification of the berries has also affected their mechanical properties which may be important, especially in view of a mechanical harvesting.

Some modifications of these properties, such as increased resistance to detachment of the pedicel, appear to hinder the work of grape harvesters, while others such as springiness and resistance to breakage of the skin, can be beneficial to better protect the integrity of the berries and thus better preserve the quality of the grapes harvested by machine.

\section{References}

ASAE, 1997. ASAE Standard S368.2: Compression test of food materials of convex shape. ASAE, St. Joseph, MI.

ASAE Standards 2011. EP497.7. Agricultural Machinery Management. St. Joseph, Mich., USA.

Baldini, E. and Intrieri, C. 1984. Meccanizzazione della vendemmia e della potatura. Ed. CLUEB, Bologna, Italy.
Bourne, M. C. 2002. Food texture and viscosity: concept and measurement. 2nd Ed., Academic Press, New York, USA.

Brancadoro, L., Maccarone, G. and Scienza, A. 1997. Potatura invernale della vite: risultati vegeto-produttivi. L'Informatore Agrario. 48:59-62.

Brancadoro, L. and Marmugi, M. 1997. Rapporto tra i sistemi di potatura invernale e tempi di lavoro nella vite. L'Informatore Agrario. 23:71-74.

Gubiani, R., Pergher, G. and Gasparinetti, P. 1994. La potatura meccanica della vite nell'ambito della meccanizzazione integrale. L'Informatore Agrario. 44:27-34.

Intrieri, C. and Poni, S. 1995. Integrated evolution of trellis training systems and machines to improve grape quality and vintage quality of mechanized italian vineyards. Am. J. Enol. Vitic. 46(1):116-126.

Intrieri, C., Silvestroni, O., Filippetti, I., Lia, G., Borghesi, L. and Colucci, E. 1999. Comportamento operativo e funzionale di "Trinova II" e di "Trinova II-Prunner" in prove di vendemmia e di potatura su "cordone libero mobilizzato. Frutticoltura. 9:89-97.

Pergher, G. and Gubiani, R. 1995. Analisi dei tempi di lavoro nella potatura del vigneto. m\&ma. 7/8:49-53.

Pezzi, F. and Bordini, F. 2006. La potatura meccanica nel vigneto: aspetti tecnici, qualitativi ed economici di differenti livelli di meccanizzazione. Rivista di Ingegneria Agraria. 1:57-65.

Pezzi, F., Balducci, G., Barca, F. and Caprara, C. 2013. Effects of Winter Pruning on Physical and Mechanical Properties of Grapes. Proc. $1^{\text {st }}$ IW on Vineyard and Mechanization \& Grape \& Wine Quality, Ed.: S. Poni, Acta Hort. 978, ISHS 2013: 347-352.

Poni, S., Bernizzoni, F., Presutto, P. and Rebucci, B. 2004. Performance of Croatina under Short-Cane Mechanical Hedging: A Successful Case of Adaptation. Am. J. Enol. Vitic. 55(4):379-388.

Rolle, L., Giacosa, S., Gerbi, V. and Novello V. 2011. Comparative Study of Texture Properties, Color Characteristics, and Chemical Composition of Ten White Table-Grape Varieties. Am. J. Enol. Vitic. March 62:49-56.

Stable Micro Systems, Texture Analyzer User Guide, UK , 2005. 